\title{
Regional opportunities and policy initiatives for new venture creation
}

Citation for published version (APA):

Verheul, I., Carree, M. A., \& Santarelli, E. (2009). Regional opportunities and policy initiatives for new venture creation. International Small Business Journal, 27(5), 608-625.

https://doi.org/10.1177/0266242609338757

Document status and date:

Published: 01/01/2009

DOI:

$10.1177 / 0266242609338757$

Document Version:

Publisher's PDF, also known as Version of record

\section{Please check the document version of this publication:}

- A submitted manuscript is the version of the article upon submission and before peer-review. There can be important differences between the submitted version and the official published version of record.

People interested in the research are advised to contact the author for the final version of the publication, or visit the DOI to the publisher's website.

- The final author version and the galley proof are versions of the publication after peer review.

- The final published version features the final layout of the paper including the volume, issue and page numbers.

Link to publication

\footnotetext{
General rights rights.

- You may freely distribute the URL identifying the publication in the public portal. please follow below link for the End User Agreement:

www.umlib.nl/taverne-license

Take down policy

If you believe that this document breaches copyright please contact us at:

repository@maastrichtuniversity.nl

providing details and we will investigate your claim.
}

Copyright and moral rights for the publications made accessible in the public portal are retained by the authors and/or other copyright owners and it is a condition of accessing publications that users recognise and abide by the legal requirements associated with these

- Users may download and print one copy of any publication from the public portal for the purpose of private study or research.

- You may not further distribute the material or use it for any profit-making activity or commercial gain

If the publication is distributed under the terms of Article $25 \mathrm{fa}$ of the Dutch Copyright Act, indicated by the "Taverne" license above, 
International Small Business Journal Copyright () 2009 SAGE Publications

(Los Angeles, London, New Delhi,

Singapore and Washington DC)

http://isb.sagepub.com

[DOI: 10.1 I 77/0266242609338757]

Vol 27(5): 608-625

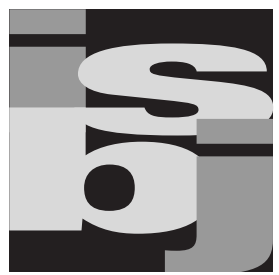

\title{
Regional Opportunities and Policy Initiatives for New Venture Creation
}

\author{
INGRID VERHEUL \\ Erasmus University Rotterdam, The Netherlands
}

MARTIN CARREE

Maastricht University, The Netherlands

\author{
ENRICO SANTARELLI \\ University of Bologna, Italy
}

This article investigates the determinants of new venture creation across industries and locations for 103 Italian provinces between 1997 and 2003. Allowing for differences in regional opportunities across industries, we investigate the impact of a range of factors, including policy initiatives, on new firm formation in manufacturing, retailing and wholesaling, hotels and restaurants. Our results show that regions with industrial districts are characterized by higher start-up rates in manufacturing and that wage costs deter entry in this industry. Firm entry in commercial sectors appears to be higher in large cities and areas with strong economic progress. For hotels and restaurants we find that tourism positively influences new firm formation. We do not find a significant effect of recently introduced regional laws promoting new firm formation in Italy.

KEYWORDS: Italian provinces; policy initiatives; venture creation

\section{Introduction}

Although a high birth rate of new enterprises is not a necessary condition for economic progress, many researchers and policy makers acknowledge the importance of continuous flows of firm entry (and exit) for economic welfare. These can be considered a seedbed of new activities from which new and successful business and industries emerge (Beesley and Hamilton, 1984). Industries and regions with low firm birth and death rates risk a misallocation of resources, formal or tacit collusion, and limited innovativeness (Geroski and Jacquemin, 1985).

There are various reasons why some regions are more attractive to start new ventures than others. Some regions have characteristics that make them fertile 
ground for firm births across a broad range of industries, while others attract firm entries in particular industries (Audretsch and Fritsch, 1999). Entrepreneurs in retailing and other small-scale services may be attracted to regions with high population density and high incomes, while entrepreneurs in manufacturing may be attracted to regions with low wages and a well-developed infrastructure. Generally, the choice for a location is driven by regional opportunities and the absence or presence of barriers to entry.

There is a growing empirical literature on the determinants of regional new firm formation. Researchers have related a wide range of determinants to the regional firm birth rate. Reynolds et al. (1994) provide a valuable overview of no less than 19 different regional characteristics and their link with firm births for regions in six countries. Their study covers all industrial sectors and focuses on manufacturing in particular. More recent studies include that of Sutaria and Hicks (2004) and Okamuro and Kobayashi (2006). Although these studies provide important insights into the factors promoting or hindering firm births, for several factors, such as the unemployment rate, mixed results have been found (Reynolds et al., 1994).

An important issue that has been neglected in existing literature is the fact that determinants of firm entry may differ across industries. In this study we stress that the presence of regional opportunities, conducive to firm births, is industrydependent. This implies that there are different factors influencing new venture creation in particular industries. More specifically, we examine the importance of technological activity (patenting), wage costs and industrial districts for starting up in manufacturing. For retailing and wholesaling we pay attention to city size, regional economic welfare and growth. For hotels and restaurants we focus on the effect of tourism. In addition to these industry-specific effects, we examine the impact of the recently introduced laws at the regional level providing entrepreneurs with direct subsidies and fiscal incentives. Policy initiatives may decrease barriers to entry, though research on their effectiveness has been rare and has shown ambiguous outcomes (Parker, 2004: 233-62).

We focus on explaining regional start-up rates in Italy, a country with three distinct 'economies': the industrial North; the rural South; and the Third Italy industrial districts economy. Together with the underdeveloped and highly imperfect capital market, this feature has important consequences for the process of firm and industry dynamics in Italy (cf. Audretsch et al., 1999). In fact, barriers to entry in manufacturing are relatively high as compared to other countries due to the high capital requirements. Yet, survival is higher for firms located in the industrial districts that characterize the North Eastern and Central Italian regions. Furthermore, Italy is reported to have the highest regulatory barriers to entrepreneurship of all OECD countries (Nicoletti and Scarpetta, 2003; Nicoletti et al., 2000). This makes Italy an interesting case for investigating the origin of regional opportunities for, and barriers to, new venture creation. The analyses incorporate a range of variables measuring opportunities for entrepreneurs in each of the 103 Italian provinces in the period between 1997 and 2003. The choice for this time period is based upon the availability of data as well as the fact that in these years several policies have been introduced to promote entrepreneurship, both at the national and regional level. 


\section{International Small Business Journal 27(5)}

Thus, the contribution of the present study is threefold. First, we investigate the differential effect of the determinants of new firm entry across industries. Furthermore, we empirically test for the effect of regional and national policies on new venture creation. Finally, we focus on a country, Italy, characterized by relatively high regulatory barriers to new venture creation as well as economic diversity within the country. The remainder of this article is organized as follows. In the next section we briefly discuss regional opportunities for new venture creation. We will pay attention in particular to the effects of the Italian regional laws aimed at promoting new firm formation. ${ }^{1}$ In the remaining sections we present the data, discuss the empirical results and conclude.

\section{Regional Opportunities, Industrial Districts and Regional Laws}

We assume that an entrepreneur would, if perfectly mobile, start up a business in the region where his or her (expected) profitability is highest. Although there are other motives for starting up a business (e.g. the wish to be independent, tax reasons, the challenge), it can be expected that the desire for new firm formation is low if there is no potential to earn a living. Assume, for convenience, that an entrepreneur $i$ wants to start a small firm and employ $L_{i}$ units of labour. The profitability of starting up in region $j$ then equals:

$$
\pi_{i j}=P_{j} Q_{i j}(L)-w_{j} L_{i}-S_{j}
$$

where $P_{j}$ is the price for the product or service in region $j ; Q_{i j}$ (.) is the production function for producing in region $j ; w_{j}$ is the wage level in region $j$; and $S_{j}$ are the start-up costs in that region. The likelihood of choosing region $j$ increases with the price and the productivity of labour, while it decreases with the wage level and the start-up costs. ${ }^{2}$

Equation (1) clearly shows why the decision for the location of a new venture may differ across industries. Some ventures (shops and restaurants) are highly dependent upon the local market, whereas others (manufacturing firms) produce products for a broader market. Although entrepreneurs of both types of ventures will be discouraged by high regional wages and start-up costs, we expect an important difference in the role of price and productivity.

Manufacturing firms that serve (inter)national markets usually do not care much about local prices because they can transport their products to regions where demand is highest and prices are favourable. These firms tend to be more concerned about labour productivity in the region since they are in need of well-trained personnel, a well-developed infrastructure and networks of clients, suppliers and other firms. Shops and restaurants depend more on local demand and price levels. Accordingly, they prefer to be located in areas with a high number of consumers, preferably with relatively high average earnings (Carree, 2002). Labour productivity in shops or restaurants often does not differ much across regions: labour is usually relatively low-skilled and there are little network advantages to achieve.

Taking into account the above considerations, we expect the effect of regionspecific factors on new venture creation to vary across industries. For example, the local wage level is likely to be positively related to local income levels and 
may have a mixed effect on venture performance of shops and restaurants. The entrepreneurs in these ventures are able to raise their product prices because of the high average earnings in the region and, at the same time, pay higher labour costs. For manufacturing firms local demand is less important and the negative effect of wage costs will dominate. Other factors, such as tourism, will be irrelevant for manufacturing firms but important for hotels and restaurants. Furthermore, the presence of networks (industrial districts) may not be important for retail firms but may be crucial for ventures in specialized manufacturing. In our empirical investigation we explore whether there is evidence for such differences.

The four elements of local demand, labour productivity, wage and start-up costs guide the choice for variables included in our empirical study. We pay specific attention to two possibly important determinants of start-up activity in Italy. First, we focus on industrial districts; a distinctive characteristic of the 'Third Italy' that may have an important impact on regional labour productivity. Second, we examine the impact of regional Italian policy initiatives on firm formation. These initiatives may reduce regional start-up costs.

Industrial districts can be seen as local production systems stimulating new firm formation through an accelerated process of labour division and specialization (Becattini, 1990; Brusco, 1982). These districts are characterized by many small firms that subcontract production to other small firms, specializing in one or a few industries and taking advantage from the local accumulation of skills (European Commission, 2002: 24; Santarelli, 2006). This accumulation results from a pooled labour market, greater provision of non traded-inputs and knowledge spillovers (Giovannetti et al., 2007; Santarelli, 2006; Soubeyran and Thisse, 1999).

Firms in these districts achieve the benefits usually associated with large-scale production by exploiting external economies, created by a learning-by-doing process that allows workers to improve their productivity through continuous exchange of information (Soubeyran and Thisse, 1999: 158). ${ }^{3}$ Small firms in cooperative networks are able to push down transaction costs, thereby increasing their likelihood of success in highly competitive international markets (Santarelli, 2006: 165). Hence, opportunities for new venture creation, especially in manufacturing, are unevenly distributed across regions. In regions with industrial districts new firm entry is easier and the likelihood of success is higher than in other regions.

Regional policies have been introduced to support new firm formation in regions with limited industry dynamics due to the absence of industrial districts and adverse environmental conditions. These policies were adopted by the regional governments soon after the introduction of National Law No. 44/1986. Most policies were introduced from the early 1990s onwards as an attempt to counter the effects of the recession, that is: increasing unemployment and a decreasing living standard of disadvantaged workers. The rationale for introducing these regional policies is that supporting new firm formation is a straightforward way to promote employment creation (Birley and Westhead, 1992). ${ }^{4}$ From the late 1990s, the level of unemployment decreased considerably, shifting the focus of small business policy in several European countries from job creation towards creating an enterprise culture (Curran, 2000). 
Despite the alleged importance of policy intervention in the entrepreneurship arena, there have been relatively few empirical studies linking enterprise policy to new firm entry. Hoffmann (2007) finds evidence for a positive relationship between the business environment, covering multiple policy areas, and performance indicators of entrepreneurship. ${ }^{5}$ Fonseca et al. (2001) find that high start-up costs, measured in terms of number of procedures and time required to complete the start-up process, lead to a decrease of the firm birth rate. Similarly, Kanniainen and Vesala (2005) show that the degree of labour market legislation has a negative impact on the rate of new firm formation across countries. According to Feldman (2001) entrepreneurial support lags rather than leads entrepreneurial activity, which would suggest that an increase in entrepreneurial activity awakes policy makers, making them aware of the economic importance of firm entry only ex-post. See Parker (2004: Chapter 10) and Storey $(1990,1998)$ for further discussion and evaluations of entrepreneurship policy.

\section{Determinants of Entry Rates in Italy}

Entry and exit rates of firms can be measured in terms of labour, assuming that a single firm represents one self-employed individual (labour market approach), or in terms of number of firms (ecological approach) (Armington and Acs, 2002). In this article, entry and exit rates are measured relative to the total labour force. ${ }^{6}$ We use data for all 103 provinces in Italy (Source: Unioncamere). As from 1996 (after Law 580/93 came into force), in Italy every new business is required to register in the Trade Register (Registro Imprese) of the local Chamber of Commerce within 30 days from start-up. Firm closures result in cancellations from the Registro Imprese within 30 days. Each year the Unioncamere (Italian Union of the Chambers of Commerce) gathers information on all firm registrations and closures from the provincial Chambers of Commerce. Unlike other data sources, the Unioncamere database also includes firms without paid employees (i.e. self-employed). In our study we exclude primary economic activity such as agriculture, fishing, forestry and mining. Table 1 gives an overview of the lowest and highest provincial entry and exit rates in Italy, presenting the seven top and bottom provinces.

There is substantial variation in entry and exit rates across provinces. We find relatively high entry rates in several provinces in Toscana (Prato, Livorno) and Emilia-Romagna (Reggio Emilia, Rimini). Although some provinces with high entry rates are characterized by a low value added per worker (Vibo Valentia), there are also 'low entry' provinces with a relatively high value added per worker (Bolzano-Bozen). The two major cities in Italy (Roma and Milano) are characterized by relatively low entry rates. We see that the 'poorest' provinces, mainly situated in the Southern part of Italy, also have the lowest exit rates. The two provinces with the lowest exit rates are on the island of Sicilia (Messina and Palermo).

There are various proxies for regional opportunities for new venture creation. Following equation (1), we concentrate on measures of local demand, labour productivity, wages and start-up costs. For local demand we include the following indicators: welfare (value added) growth, tourism and city size. For labour productivity we incorporate not only a general per capita measure but also measures 
Verheul et al.: Regional Opportunities and Policy Initiatives for New Venture Creation

Table 1. Provincial Entry and Exit Rates

\begin{tabular}{llllll}
\hline Province & $\begin{array}{l}\text { Entry Rate } \\
\text { (Average) }\end{array}$ & $\begin{array}{l}\text { Value Added } \\
\text { PerWorker* }\end{array}$ & Province & $\begin{array}{l}\text { Exit Rate } \\
\text { (Average) }\end{array}$ & $\begin{array}{l}\text { Value Added } \\
\text { PerWorker* }\end{array}$ \\
\hline Messina & 5.41 & 33.4 & Messina & 4.10 & 33.4 \\
Biella & 6.19 & 47.1 & Palermo & 4.37 & 33.9 \\
Bolzano-Bozen & 6.33 & 54.7 & Reggio Calabria & 4.39 & 29.8 \\
Roma & 6.38 & 50.9 & Roma & 4.46 & 50.9 \\
Lodi & 6.52 & 40.6 & Catania & 4.74 & 32.1 \\
Sondrio & 6.54 & 41.5 & Nuoro & 4.75 & 34.2 \\
Milano & 6.63 & 62.3 & Napoli & 4.80 & 32.8 \\
& $\ldots \ldots$ & & & $\ldots .$. & \\
Rovigo & 8.57 & 39.1 & Torino & 7.00 & 48.7 \\
Prato & 8.60 & 43.9 & Ferrara & 7.04 & 40.0 \\
ViboValentia & 8.60 & 28.7 & Livorno & 7.07 & 44.8 \\
Caserta & 8.75 & 33.2 & Udine & 7.08 & 48.2 \\
Rimini & 8.79 & 47.5 & Rimini & 7.09 & 47.5 \\
Livorno & 8.84 & 44.8 & Savona & 7.46 & 48.8 \\
Reggio Emilia & 9.64 & 47.2 & Prato & 7.96 & 43.9 \\
\hline
\end{tabular}

Note:The seven provinces with the lowest entry and exit rates are presented in the upper part of the table, while the seven provinces with the highest rates are presented in the lower part. Average yearly rates are presented for the period 1997-2003. *Value added per worker is measured in 1000 euro per labour force.

of technological activity (patenting) and the presence of industrial districts. We measure wage costs directly at the more aggregated regional level. Note that wages are costs to the business and at the same time lead to an increase in local demand. In terms of start-up costs we concentrate upon national and regional regulations. Below you find more detailed information on the nine variables incorporated in our empirical analysis:

1. Time dummies are included because of the relaxation of entry regulation in Italy in the period under consideration. For example, Schivardi and Viviano (2007) discuss the 1998 Bersani Law that reformed the Italian retail trade sector. ${ }^{7}$ Obviously, time dummies also correct for other national time-specific effects.

2. The variable patents captures the (potential) effect of technological intensity on new firm formation and is measured by the number of patents in 2003 per 1000 firms (source: Unioncamere). Following Armington and Acs (2002) we allow firm entry (and exit) rates to differ between low-tech and high-tech regions. Choi and Phan (2006) find that patent application per capita are negatively associated with new firm formation in the USA and argue that patents are an indicator of venture success rather than a cause of firm formation. However, they use nationwide time-series data instead of regional panel data. Fritsch and Falck (2007) find no clear effect of the number patents per employee on total new business formation but a positive effect for the manufacturing sector. 
3. The variable growth is measured by the relative change in the provincial value added (valore aggiunto a prezzi base - al netto dei SIFIM, source: ISTAT) in the previous period. Most studies at the industry level have found a positive and significant effect of profitability and market growth on both gross and net entry (Carree and Thurik, 1996). We want to test whether the same effect arises at the provincial level. A thriving economy may be important in particular for firms that depend upon the local market.

4. The variable tourists is measured as the ratio of number of tourists to the labour force and represents the extent to which the provincial economy benefits from tourism. Regions with high levels of tourism, such as Firenze and Venezia, may be characterized by high start-up rates in certain industries such as hotels and restaurants, but these rates may diminish when a certain threshold of tourist activity is reached. Overexploitation of local resources due to mass tourism may be a reason for firms to abandon central locations (Russo, 2002).

5. The variable city is a dummy variable with value 1 for the four largest cities in terms of population (Torino, Milano, Napoli and Roma) and 0 otherwise. We control for the possibility that provinces with large Italian metropolitan cities display relatively high entry rates for certain industries. ${ }^{8}$ This is consistent with Reilly's Law (Reilly, 1931) positing that the larger the city, the larger the trade area around it. Large metropolitan areas are likely to attract new firms in the surrounding area (Fotopoulos and Louri, 2000). Other studies have alluded to the attractiveness of urban areas for new firm formation, including the 'inner-city incubator' hypothesis by Vernon (1960) and the 'filtering down' hypothesis by Thompson (1968).

6. The presence of industrial districts is captured by the dummy variable inddist with value 1 for provinces with at least one industrial district, and 0 otherwise (source: Unioncamere). There are 22 provinces with inddist equal to $1 .{ }^{9} \mathrm{We}$ expect that in regions with industrial districts entry rates in manufacturing are higher.

7. The variable wage represents the regional (manufacturing) wage level (source: ISTAT). This variable is only available at the aggregate level of the 20 Italian regions and not at the provincial level. High wage levels are expected to have a negative effect on firm entry and a positive effect on firm exit. High wages imply high (opportunity) costs for the self-employed. Studies by Ashcroft et al. (1991) and Santarelli and Piergiovanni (1995) show that the average annual wage per employee has a negative effect on new firm formation at the county level in Great Britain and the provincial level in Italy, respectively. The effect is likely to be stronger for firms in manufacturing and advanced service sectors (producer services) than for firms that depend heavily on the local market.

8. Value added per capita, $v a p c$, is based on provincial value added data. Including this variable controls for the fact that the North, South and Central parts of Italy differ in terms of level of development and productivity. A productive labour force is expected to have a positive effect on new firm formation in all sectors.

9. From the early 1990 s onwards the 20 regions in Italy have been introducing laws to promote firm formation. These laws may take various forms, such as 
direct subsidies and fiscal incentives. The variable laws measures the number of laws introduced in the previous four years in the region where the province is located. Between 1993 and 2003 a total of 78 regional laws were introduced (Piergiovanni et al., 2007: 216). ${ }^{10}$ In general these laws aimed at reducing financial and administrative start-up costs.

Table 2 presents summary statistics (means and standard deviations) for all variables included in the empirical analysis.

\section{Empirical Results}

The results for the entry models are presented in Tables 3 and 4. The top part of the tables presents the year-specific fixed effects (y1997 through y2003). The bottom part shows the results for the eight other explanatory variables. In Table 4 we added the effect of exit in the same period and province for two reasons. First, a considerable share of entrants represent takeovers of existing companies. Although the entrepreneur who acquires the business may deliberately choose to enter that province, de novo entry and takeover may differ. Second, exits may also present a market opportunity. Closing firms may be replaced by new entrants filling in the resulting market room. Below we discuss both results, including and excluding exit.

In terms of the year-specific effects we see an increase in new firm formation over the years, starting at a low level in 1997 and 1998, and increasing to a higher level in the period after 1999. We do not observe a similar time effect for exit rates. Hence, the increased (gross) entry in the period between 1997 and 2003 may be an indication of policy changes at the national level in the 1990s. Santarelli and Vivarelli (2002) report that this period is characterized by deregulation and the introduction of entry subsidies (mostly soft loans). The year-specific effects occur in retailing and wholesaling, but not in the other industries. This may be explained by the fact that the Bersani Law of 1998 aimed at stimulating deregulation of the retail sector.

Table 2. Summary Statistics

\begin{tabular}{llcl}
\hline Variable & Description & Mean & SD \\
\hline Entry & Entry rate & 13.97 & 3.91 \\
Exit & Exit rate & 11.09 & 3.28 \\
Net entry & Net entry rate & 2.88 & 2.67 \\
Patents & Number of patents per firm & 0.954 & 1.392 \\
Growth & Value added growth rate & 0.045 & 0.025 \\
Tourists & Number of tourists per labour force & 3.73 & 3.92 \\
City & Dummy 4 largest cities & 0.039 & 0.193 \\
Vapc & Value added per capita & 16.86 & 4.29 \\
Inddist & Industrial district dummy & 0.214 & 0.410 \\
Wage & Average wage level & 15.45 & 1.65 \\
Laws & Number of laws to promote firm formation & 1.62 & 1.50 \\
\hline
\end{tabular}

Note: Average values are presented for a seven-year period. 
International Small Business Journal 27(5)

There appears to be little effect of patent activity on entry. In Table 3 we see a negative effect for the manufacturing sector, although this effect is no longer present in Table 4, when including exit. The results suggest that gross entry in manufacturing is low in provinces characterized by high rates of patenting. Because patenting activity is undertaken mainly by a limited number of large firms in specific industries, the patents variable may not adequately capture technological opportunities for small firms (Choi and Phan, 2006).

Growth in provincial value added (in the previous period) has the expected positive effect on entry in Table 4 . The effects are significant for the economy as a whole and for the retail and wholesale sector. In thriving provincial economies more

Table 3. Estimation Results for Gross Rates of Entry, Excluding Exit

\begin{tabular}{|c|c|c|c|c|}
\hline Sector & All & Manufacturing & Commerce & HotRest \\
\hline y1997 & $\begin{array}{l}\text { I5.93*** } \\
(1.49)\end{array}$ & $\begin{array}{l}2.80 \text { **** } \\
(0.30)\end{array}$ & $\begin{array}{l}6.67 * * * * \\
(0.48)\end{array}$ & $\begin{array}{l}0.65^{* * * *} \\
(0.16)\end{array}$ \\
\hline y1998 & $\begin{array}{l}\text { I5.83*** } \\
(1.49)\end{array}$ & $\begin{array}{l}2.92 * * * \\
(0.31)\end{array}$ & $\begin{array}{l}6.58^{* * * *} \\
(0.49)\end{array}$ & $\begin{array}{l}0.62^{* * * *} \\
(0.16)\end{array}$ \\
\hline y1999 & $\begin{array}{l}18.92 \text { **** } \\
(1.53)\end{array}$ & $\begin{array}{l}2.75^{* * * *} \\
(0.31)\end{array}$ & $\begin{array}{l}6.83^{* * * * *} \\
(0.50)\end{array}$ & $\begin{array}{l}0.49 * * * \\
(0.17)\end{array}$ \\
\hline y2000 & $\begin{array}{l}19.99 * * * \\
(1.56)\end{array}$ & $\begin{array}{l}2.64 * * * * \\
(0.32)\end{array}$ & $\begin{array}{l}7.44 * * * * \\
(0.51)\end{array}$ & $\begin{array}{l}0.36 * * \\
(0.17)\end{array}$ \\
\hline y200I & $\begin{array}{l}20.32 \text { **** } \\
(1.63)\end{array}$ & $\begin{array}{l}2.70 \text { *** } \\
(0.33)\end{array}$ & $\begin{array}{l}7.4 I^{\text {***** }} \\
(0.53)\end{array}$ & $\begin{array}{c}0.37^{*} \\
(0.18)\end{array}$ \\
\hline y2002 & $\begin{array}{l}20.32 * * * \\
(1.68)\end{array}$ & $\begin{array}{l}2.63 * * * \\
(0.34)\end{array}$ & $\begin{array}{l}7.48^{* * * *} \\
(0.54)\end{array}$ & $\begin{array}{l}0.43^{* *} \\
(0.18)\end{array}$ \\
\hline y2003 & $\begin{array}{l}19.46 \text { *** } \\
(1.71)\end{array}$ & $\begin{array}{l}2.50^{* * * * *} \\
(0.35)\end{array}$ & $\begin{array}{l}7.37^{* * * * *} \\
(0.55)\end{array}$ & $\begin{array}{l}0.39 \text { ** } \\
(0.19)\end{array}$ \\
\hline Patents & $\begin{array}{c}-0.191 \\
(0.124)\end{array}$ & $\begin{array}{l}-0.070 * * * \\
(0.025)\end{array}$ & $\begin{array}{c}0.037 \\
(0.040)\end{array}$ & $\begin{array}{c}-0.012 \\
(0.013)\end{array}$ \\
\hline Growth & $\begin{array}{c}2.889 \\
(5.988)\end{array}$ & $\begin{array}{c}0.915 \\
(1.223)\end{array}$ & $\begin{array}{c}2.755 \\
(1.945)\end{array}$ & $\begin{array}{c}-0.147 \\
(0.652)\end{array}$ \\
\hline Tourists & $\begin{array}{c}0.031 \\
(0.038)\end{array}$ & $\begin{array}{l}-0.042 * * * \\
(0.008)\end{array}$ & $\begin{array}{c}0.008 \\
(0.012)\end{array}$ & $\begin{array}{l}0.039 * * * \\
(0.004)\end{array}$ \\
\hline City & $\begin{array}{c}0.932 \\
(0.731)\end{array}$ & $\begin{array}{c}-0.246 * \\
(0.149)\end{array}$ & $\begin{array}{l}0.648 * * * \\
(0.238)\end{array}$ & $\begin{array}{l}-0.221 * * * \\
(0.080)\end{array}$ \\
\hline Inddist & $\begin{array}{c}0.667^{* *} \\
(0.340)\end{array}$ & $\begin{array}{l}0.453^{* * *} \\
(0.069)\end{array}$ & $\begin{array}{c}0.016 \\
(0.111)\end{array}$ & $\begin{array}{c}-0.036 \\
(0.037)\end{array}$ \\
\hline Wage & $\begin{array}{l}-0.578 * * * \\
(0.116)\end{array}$ & $\begin{array}{l}-0.159 * * * \\
(0.024)\end{array}$ & $\begin{array}{l}-0.124 * * * \\
(0.038)\end{array}$ & $\begin{array}{c}-0.000 \\
(0.013)\end{array}$ \\
\hline Vacap & $\begin{array}{l}0.229 * * * \\
(0.053)\end{array}$ & $\begin{array}{l}0.083^{* * * *} \\
(0.011)\end{array}$ & $\begin{array}{l}-0.098 * * * \\
(0.017)\end{array}$ & $\begin{array}{c}0.009 \\
(0.006)\end{array}$ \\
\hline Laws & $\begin{array}{c}0.074 \\
(0.096)\end{array}$ & $\begin{array}{c}0.021 \\
(0.020)\end{array}$ & $\begin{array}{c}-0.004 \\
(0.031)\end{array}$ & $\begin{array}{c}0.008 \\
(0.010)\end{array}$ \\
\hline $\mathrm{R}^{2}$ & 0.231 & 0.242 & 0.179 & 0.233 \\
\hline
\end{tabular}

Note: Standard errors between brackets. Number of observations is 721 . ***, *** and * refer significance levels of $1 \%, 5 \%$ and $10 \%$, respectively. 
Verheul et al.: Regional Opportunities and Policy Initiatives for New Venture Creation Table 4. Estimation Results for Gross Rates of Entry, Including Exit

\begin{tabular}{|c|c|c|c|c|}
\hline Sector & All & Manufacturing & Commerce & HotRest \\
\hline \multirow[t]{2}{*}{ y1997 } & $2.52 * * *$ & $0.61 * * *$ & $1.72 * * *$ & $0.35^{* * *}$ \\
\hline & $(0.80)$ & $(0.16)$ & $(0.33)$ & $(0.10)$ \\
\hline \multirow[t]{2}{*}{ y1998 } & $3.88 * * *$ & $0.89 * * *$ & $1.92 * * *$ & $0.41^{* * * *}$ \\
\hline & $(0.79)$ & $(0.16)$ & $(0.33)$ & $(0.10)$ \\
\hline \multirow[t]{2}{*}{ y1999 } & $7.20 * * *$ & $0.81 * * *$ & $2.07^{* * * *}$ & $0.30 * * *$ \\
\hline & $(0.81)$ & $(0.16)$ & $(0.33)$ & $(0.10)$ \\
\hline \multirow[t]{2}{*}{ y2000 } & $8.23 * * *$ & $0.75 * * *$ & $2.64 * * *$ & $0.20 *$ \\
\hline & $(0.82)$ & $(0.17)$ & $(0.34)$ & $(0.11)$ \\
\hline \multirow[t]{2}{*}{ y200I } & $8.63^{* * *}$ & $0.84 * * *$ & $2.68 * * *$ & $0.24 * *$ \\
\hline & $(0.85)$ & $(0.17)$ & $(0.35)$ & $(0.11)$ \\
\hline \multirow[t]{2}{*}{ y2002 } & $7.87 * * *$ & $0.67 * * *$ & $2.58 * * *$ & $0.28 * *$ \\
\hline & $(0.88)$ & $(0.18)$ & $(0.36)$ & $(0.11)$ \\
\hline \multirow[t]{2}{*}{ y2003 } & $7.87 * * *$ & $0.62 * * *$ & $2.65 * * *$ & $0.29 * *$ \\
\hline & $(0.89)$ & $(0.18)$ & $(0.37)$ & $(0.12)$ \\
\hline \multirow[t]{2}{*}{ Patents } & -0.011 & 0.000 & 0.031 & 0.002 \\
\hline & $(0.062)$ & $(0.013)$ & $(0.025)$ & $(0.008)$ \\
\hline \multirow[t]{2}{*}{ Growth } & $6.816^{* *}$ & 0.586 & $3.204 * * *$ & 0.411 \\
\hline & $(2.995)$ & $(0.622)$ & $(1.189)$ & $(0.404)$ \\
\hline \multirow[t]{2}{*}{ Tourists } & 0.023 & $-0.011 * * *$ & 0.001 & -0.002 \\
\hline & $(0.019)$ & $(0.004)$ & $(0.008)$ & $(0.003)$ \\
\hline \multirow[t]{2}{*}{ City } & $1.288^{*} * *$ & -0.111 & $0.595 * * *$ & 0.015 \\
\hline & $(0.366)$ & $(0.076)$ & $(0.145)$ & $(0.050)$ \\
\hline \multirow[t]{2}{*}{ Inddist } & $0.374^{* *}$ & $0.062 *$ & 0.096 & 0.012 \\
\hline & $(0.170)$ & $(0.036)$ & $(0.068)$ & $(0.023)$ \\
\hline \multirow[t]{2}{*}{ Wage } & $-0.14 I^{* *}$ & $-0.026 * *$ & -0.008 & 0.000 \\
\hline & $(0.059)$ & $(0.012)$ & $(0.023)$ & $(0.008)$ \\
\hline \multirow[t]{2}{*}{ Vacap } & $-0.114^{* * *}$ & -0.005 & $-0.105^{* * *}$ & $-0.011 * * *$ \\
\hline & $(0.028)$ & $(0.006)$ & $(0.011)$ & $(0.004)$ \\
\hline \multirow[t]{2}{*}{ Laws } & 0.019 & 0.006 & 0.010 & 0.000 \\
\hline & $(0.048)$ & $(0.010)$ & $(0.019)$ & $(0.007)$ \\
\hline \multirow[t]{2}{*}{ Exit } & $0.986 * * *$ & $0.747 * * *$ & $0.759 * * *$ & $0.794 * * *$ \\
\hline & $(0.021)$ & $(0.017)$ & $(0.022)$ & $(0.024)$ \\
\hline $\mathrm{R}^{2}$ & 0.808 & 0.804 & 0.694 & 0.706 \\
\hline
\end{tabular}

Note: Standard errors between brackets. Number of observations is 721 . ***, *** and * refer significance levels of $1 \%, 5 \%$ and $10 \%$, respectively.

commercial firms start and survive. Tourism has a significant negative effect on entry in the manufacturing sector. Apparently, tourism and an influx of manufacturing firms do not go well together. Tourism has a positive effect on the firm birth rate for hotels and restaurants, but the effect disappears when the exit rate is accounted for in Table 4.

Entry is found to be higher in the four largest cities. It seems that in the period under consideration there were still substantial agglomeration effects. However, there is a difference in the effect for manufacturing and commercial firms. 
For manufacturing the effect is negative, while for retailing and wholesaling it is positive. The space or land that can be used for manufacturing purposes may be quite scarce in the surroundings of the largest cities, thereby forcing these activities to relocate to other regions. Retail and wholesale firms appear to benefit from the presence of a large population.

The presence of industrial districts has a significant positive effect on entry in all industries and in manufacturing, suggesting that these districts are fruitful areas for new and small firms. The wage variable has the expected negative effect on firm entry, indicating that high regional wages discourage entrants. As expected, this mainly holds for the manufacturing sector. For hotels and restaurants wage costs do not play a crucial role as new ventures may be able to benefit from the higher local demand in high-income areas.

The results in Table 3 show that provinces with high labour productivity attract new manufacturing firms. However, this effect disappears in Table 4. Value added per capita does not affect entry in the hotel and restaurant industry and has even a negative effect for the retail and wholesale industry. The latter, counterintuitive, result may be explained by the higher opportunity costs of starting a retail or wholesale venture in areas where labour is highly productive in other sectors.

We find no effect of the regional laws designed to support entrepreneurial activity (in the previous four years) on firm entry. It appears that regional government policy does not play an instrumental role in creating an entrepreneurial culture. It should be noted that we use a simple count of policy initiatives in the previous four years and do not take into account their relative importance. Nevertheless, our results suggest that activity in the entrepreneurship policy arena, leading to the design and implementation of many different measures to stimulate firm entry, does not lead to the desired results.

\section{Conclusions}

This article investigates the determinants of new venture creation across industries and locations. The focus is on the way in which regional opportunities have influenced firm entry in 103 Italian provinces between 1997 and 2003. We allow regional opportunities to differ across industries and examine the impact of a range of factors on start-up activity in manufacturing, retailing and wholesaling, and hotels and restaurants. We test for the importance of technological activity, wage costs and industrial districts for start-ups in manufacturing. Our results show that regional wage costs limit entry, while provinces with industrial districts achieve higher startup rates in manufacturing. For the retail and wholesale sector attention is paid, in particular, to city size and regional economic welfare and growth. Our results confirm the expectation that start-up rates in the commercial industry are higher in large cities and in areas that show strong economic progress. For hotels and restaurants we include tourism as an explanatory factor and find that the relative number of tourists significantly influences new firm formation in this industry.

In our analysis we also incorporate a variable measuring the (recent) introduction of laws at the regional level providing fiscal incentives and direct subsidies to entrepreneurs. These laws are aimed at bringing down start-up costs for entrepreneurs who want to enter a particular industry. We do not find a significant effect 
of recently introduced laws on firm entry rates for all industries incorporated in our analysis. This suggests that regional governments have a relatively limited role in promoting entrepreneurial activity. Nevertheless, the results indicate that the national Bersani Law of 1998 aimed at deregulation was effective in raising entry rates in the commercial sector in Italy. Apparently, national policy initiatives to achieve deregulation are more successful in stimulating start-up activity than introducing subsidies at the regional level. Furthermore, our results show that the 'traditional' industrial districts provide fertile ground for new manufacturing firms. This warrants further study of the role of industrial districts in stimulating new venture creation in Italy as well as the role of the government in creating an enterprise culture by supporting the development of such districts.

From a policy perspective, this study shows that regional policies targeting entrepreneurship do not necessarily yield positive results. To avoid the waste of limited funding and taxpayer's money, it is important for local governments to carefully consider the objectives of the policies they introduce, and accurately monitor and evaluate the impact of such policies. Note that in this study we use a crude (count) measure of regional policies, which does not capture the full complexity of government policies introduced in the Italian provinces. Nevertheless, it shows that merely introducing some policies to stimulate entrepreneurship may not be sufficient for reaching this goal.

Regions providing ample opportunities for entrepreneurial activity will not only have their own inhabitants starting up new firms, but will also attract (potential) entrepreneurs from other regions. From this perspective investigating the characteristics of the supply of entrepreneurship from within the region can be considered a partial approach at best. Also note that we use a narrow interpretation of start-up costs, as these costs do not capture sunk and location costs which could very well differ across regions. Furthermore, we did not take into account the size of the entrants as there was no information available on this. Finally, one should be careful when applying the results obtained in this study to regions in other countries as Italy has distinct characteristics (e.g. high regulatory burden and regional diversity) when compared to other European countries.

\section{Acknowledgement}

Enrico Santarelli acknowledges financial support from MIUR (PRIN 2006, 'Innovation, Entrepreneurship, and Competitiveness of Italian Firms in the High-Tech Industries; protocol \#2006132439). Previous versions of this article have been presented at the 6th Annual International Industrial Organization Conference, Marymount University, Arlington (VA, USA), May 2008, and at the 35th Annual Conference of the European Association for Research in Industrial Economics, Toulouse (France), September 2008. We want to thank two anonymous referees for their useful suggestions.

\section{Notes}

1. We are grateful to Roberta Piergiovanni for collecting these data. For a more elaborate discussion see Piergiovanni et al. (2007).

2. Another possible interpretation using equation (1) is that individuals of the labour force in region $j$ stay in their region but choose between starting a venture, earning a profit, and 


\section{International Small Business Journal 27(5)}

remaining employed (or unemployed). This does not alter the rest of our discussion: price and productivity have a positive effect and wage and start-up costs a negative one.

3. This definition is consistent with the hypothesis put forward by Fujita and Thisse (2002) who identify the centripetal effect exerted by localized positive externalities as one of the main factors producing the economic landscapes where agglomeration of economic activities is determined.

4. This is the case for most industrial policies in the European Union.

5. Hoffmann (2007: 162) includes the following policy indicators: tech-transfer regulation, entry barriers, access to foreign markets, loans, venture capital, bankruptcy or exit legislation, fiscal legislation, restart opportunities, entrepreneurship and business education, administrative burden, labour market legislation and indicators of entrepreneurial culture.

6. We also examined the results including entry and exit rates relative to the number of incumbent firms (in the previous period). These results are very similar to those including entry and exit rates relative to total labour force.

7. Before the introduction of the Bersani Law new retail establishments were required to have a permit from the town council. The Bersani Law abolished this requirement and small outlets now have to hand in a notification. See Carree and Nijkamp (2001) for the estimated effects of a similar deregulation on entry and exit rates in Dutch retailing.

8. Studies by Garofoli (1994) and Santarelli and Piergiovanni (1995) found contrasting evidence for this hypothesis.

9. Provinces with at least one important 'traditional' (according to the definition used by Unioncamere) industrial district are: Ascoli Piceno (shoes), Arezzo (golden jewelry), Avellino (leather), Bari (footwear), Biella (textiles - wool), Brescia (metal household artefacts and machinery for textile industry), Como (silk), Ferrara (mechanical engineering), Macerata (leather products), Mantova (stockings), Modena (knitwear and biomedical industry and ceramics), Pisa (leather), Pordenone (cutlery)), Prato (textiles), Parma (ham), Pesaro-Urbino (furniture), Pavia (machinery for the footwear industry), Siena (furniture), Treviso (sporting footwear), Vicenza (leather), Verona (furniture) and Viterbo (ceramics). Note that the definition of industrial district used here excludes local systems dominated by 'focal' or leading firms occupying strategic and central positions due to their extensive network of customers and suppliers. For a further specification, see Lazerson and Lorenzoni (1999).

10. It is interesting to observe that many of these regional laws targeted young and female entrepreneurs.

\section{References}

Armington, C. and Acs, Z. J. (2002) 'The Determinants of Regional Variation in New Firm Formation', Regional Studies 36(1): 33-45.

Ashcroft, B., Love, J. H. and Malloy, E. (1991) 'New Firm Formation in the British Counties with Special Reference to Scotland', Regional Studies 25: 395-409.

Audretsch, D. B. and Fritsch, M. (1999) 'The Industry Component of Regional New Firm Formation Processes', Review of Industrial Organization 15(3): 239-52.

Audretsch, D. B., Santarelli, E. and Vivarelli, M. (1999) 'Start-up Size and Industrial Dynamics: Some Evidence from Italian Manufacturing', International Journal of Industrial Organization 17(7): 965-83.

Becattini, G. (1990) 'The Marshallian Industrial District as a Socio-economic Notion', in F. Pyke, G. Becattini and D. Sengenberger (eds) Industrial Districts and Inter-Firm Cooperation in Italy, pp. 35-71. Geneva: ILO. 
Beesley, M. E. and Hamilton, R. T. (1984) 'Small Firms' Seedbed Role and the Concept of Turbulence', Journal of Industrial Economics 33(2): 217-31.

Birley, S. and Westhead, P. (1992) 'A Comparison of New Firms in Assisted and Non-assisted Areas in Great Britain', Entrepreneurship and Regional Development 4(4): 299-338.

Brusco, S. (1982) 'The Emilian Model: Productive Decentralization and Social Integration', Cambridge Journal of Economics 6: 167-84.

Carree, M. A. (2002) 'Does Unemployment Affect the Number of Establishments?: A Regional Analysis for US States', Regional Studies 36(4): 389.

Carree, M. A. and Nijkamp, J. (2001) 'Deregulation in Retailing: The Dutch Experience', Journal of Economics and Business 53(2-3): 225-35.

Carree, M. A. and Thurik, A. R. (1996) 'Entry and Exit in Retailing: Incentives, Barriers, Displacement and Replacement', Review of Industrial Organization 11(2): 155-72.

Choi, Y. R. and Phan, P. H. (2006) 'The Influences of Economic and Technology Policy on the Dynamics of New Firm Formation', Small Business Economics 26(4): 493-503.

Curran, J. (2000) 'What is Small Business Policy in the UK for?: Evaluation and Assessing Small Business Policies', International Small Business Journal 18(3): 36-50.

European Commission (2002) Regional Clusters in Europe, Observatory of European SMEs, No. 3, Brussels: European Commission.

Feldman, M. P. (2001) 'The Entrepreneurial Event Revisited: Firm Formation in a Regional Context', Industrial and Corporate Change 10: 861-91.

Fonseca, R., Lopez-Garcia, P. and Pissarides, C. A. (2001) 'Entrepreneurship, Start-up Costs and Employment', European Economic Review 45(4-6): 692-705.

Fotopoulos, G. and Louri, H. (2000) 'Location and Survival of New Entry', Small Business Economics 14: 311-21.

Fritsch, M. and Falck, O. (2007) 'New Business Formation by Industry over Space and Time: A Multidimensional Analysis', Regional Studies 41(2): 157-72.

Fujita, M. and Thisse, J. F. (2002) Economics of Agglomeration: Cities, Industrial Location, and Regional Growth. Cambridge: Cambridge University Press.

Garofoli, G. (1994) 'New Firm Formation and Regional Development: The Italian Case', Regional Studies 28(4): 381-93.

Geroski, P. A. and Jacquemin, A. (1985) 'Industrial Change, Barriers to Mobility, and European Industrial Policy', Economic Policy 1: 169-204.

Giovannetti, E., Neuhoff, K. and Spagnolo, G. (2007) 'Trust and Virtual Districts: Evidence from the Milan Internet Exchange', Metroeconomica 58(2): 436-56.

Hoffmann, A. N. (2007) 'A Rough Guide to Entrepreneurship Policy', in D. B. Audretsch, I. Grilo and A. R. Thurik (eds) Handbook of Research on Entrepreneurship Policy, pp. 140-71. Cheltenham and Northampton: Edward Elgar.

Kanniainen, V. and Vesala, T. (2005) 'Entrepreneurship and Labor Market Institutions', Economic Modelling 22(5): 828-47.

Lazerson, M. and Lorenzoni, G. (1999) 'Resisting Organizational Inertia: The Evolution of Industrial Districts', Industrial and Corporate Change 3(3): 361-77.

Nicoletti, G. and Scarpetta, S. (2003) 'Regulation, Productivity and Growth: OECD Evidence', Economic Policy 18(36): 9-72.

Nicolleti, G., Scarpetta, S. and Boylaud, O. (2000) 'Summary Indicators of Product Market Regulation with an Extension to Employment Protection Legislation', OECD Economics Department Working Papers No. 226, OECD Publishing.

Okamuro, H. and Kobayashi, N. (2006) 'The Impact of Regional Factors on the Start-up Ratio in Japan', Journal of Small Business Management 44(2): 310-13.

Parker, S. C. (2004) The Economics of Self-Employment and Entrepreneurship. Cambridge: Cambridge University Press. 
Piergiovanni, R., Carree, M., Santarelli, E. and Verheul, I. (2007) 'Politiche per l'imprenditorialità e Self-employment: Un'analisi Territoriale', l'Industria 28(2): 199-219.

Reilly, W. J. (1931) The Law of Retail Gravitation. New York: Knickerbocker Press.

Reynolds, P., Storey, D. J. and Westhead, P. (1994) 'Cross-national Comparisons of the Variation in New Firm Formation Rates', Regional Studies 28(4): 443-56.

Russo A. P. (2002) 'The "Vicious Circle" of Tourism Development in Heritage Cities', Annals of Tourism Research 29(1): 165-82.

Santarelli, E. (2006) 'Entrepreneurship, Innovation, and the Evolution of Industrial Districts', in E. Santarelli (ed.) Entrepreneurship, Growth, and Innovation: The Dynamics of Firms and Industries, pp. 165-82. New York: Springer.

Santarelli, E. and Piergiovanni, R. (1995) 'The Determinants of Firm Start-up and Entry in Italian Producer Services', Small Business Economics 7(3): 221-30.

Santarelli, E. and Vivarelli, M. (2002) 'Is Subsidizing Entry an Optimal Policy?', Industrial and Corporate Change 11(1): 39-52.

Schivardi, F. and Viviano, E. (2007) 'Entry Barriers in Italian Retail Trade', Banca d'Italia Temi di discussione No. 616, Rome.

Soubeyran, A. and Thisse, J. F. (1999) 'Learning-by-doing and the Development of Industrial Districts', Journal of Urban Economics 45(1): 156-76.

Storey, D. J. (1990) 'Evaluation of Policies and Measures to Create Local Employment', Urban Studies 27(5): 669-84.

Storey, D. J. (1998) 'Six Steps to Heaven: Evaluating the Impact of Public Policies to Support Small Businesses in Developed Economies', CSME Working Paper 59, Warwick Business School, Small and Medium Sized Enterprise Centre.

Sutaria, V. and Hicks, D. A. (2004) 'New Firm Formation: Dynamics and Determinants', Annals of Regional Science 35(3): 241-62.

Thompson, W. (1968) 'Internal and External Factors in the Development of Urban Economies', in H. S. Perloff and L. Wingo (eds) Issues in Urban Economics, pp. 43-62. Washington, DC: The Johns Hopkins Press for Resources for the Future.

Unioncamere (2002) Osservatorio Unioncamere sulla Demografia delle Imprese. Roma: Unioncamere.

Vernon, R. R. (1960) Metropolis 1985. Cambridge, MA: Harvard University Press.

INGRID VERHEUL, PhD Erasmus School of Economics, Erasmus University Rotterdam. Assistant Professor of Entrepreneurship at Rotterdam School of Management, Erasmus University Rotterdam, Centre for Entrepreneurship and New Business Venturing. Research interests: female entrepreneurship, determinants of entrepreneurship, new firm entry and exit, entrepreneurship education. Please address correspondence to: Ingrid Verheul, School of Management Rotterdam, Erasmus University, Centre for Entrepreneurship and New Business Venturing, 3000 DR Rotterdam,The Netherlands. [email: verheul@few.eur.nl]

MARTIN CARREE, PhD Erasmus University Rotterdam, Full Professor of Industrial Organisation at Maastricht University, Department of Organisation and Strategy, School of Business and Economics. Research interests: new firm entry; entrepreneurship and growth; small business economics; competition policy; female entrepreneurship; applied econometrics; innovation. Please address correspondence to: Martin Carree, Maastricht University, Faculty of Economics and Business Administration, P.O. Box 616, 6200 MD Maastricht,The Netherlands. [email: m.carree@maastrichtuniversity.nl] 
ENRICO SANTARELLI, PhD University of Sussex. Full Professor of Economics and Entrepreneurship at University of Bologna, Department of Economics, Faculty of Statistics.

Research Professor at the Max Planck Institute of Economics, Jena. Member of the Executive Committee of the European Association for Research in Industrial Economics (EARIE). Research interests: Patent analysis; new-firm entry, growth, and survival; entrepreneurship and growth; regional economics; small business economics; competition policy and antitrust legislation; evaluation of public policies. His most recent book is Entrepreneurship, Growth, and Innovation:The Dynamics of Firms and Industries (Springer, 2006). Please address correspondence to: Enrico Santarelli, University of Bologna, Department of Economics, Piazza Scaravilli, 2, I-40 I 26 Bologna, Italy. [email: enrico.santarelli@unibo.it]

\title{
Possibilités régionales et initiatives stratégiques présidant à la création de nouvelles entreprises
}

\author{
Ingrid Verheul \\ Université Erasmus de Rotterdam, Pays-Bas \\ Martin Carree \\ Université de Maastricht, Pays-Bas \\ Enrico Santarelli \\ Université de Bologne, Italie
}

Le présent article analyse quels ont été les facteurs déterminants de la création de nouvelles entreprises dans les secteurs et les sites industriels de 103 provinces italiennes, entre 1997 et 2003. Tout en tenant compte des différences que présentent les possibilités régionales dans toutes les industries, nous étudions les conséquences que peuvent avoir un certain nombre de facteurs - dont les initiatives stratégiques - sur la création de nouvelles entreprises dans les domaines de la fabrication, du commerce de détail et de gros, de l'hôtellerie et de la restauration. Les résultats que nous avons obtenus indiquent que les régions dotées de zones industrielles se caractérisent par des taux de démarrage d'entreprises manufacturières plus élevés et que les charges salariales découragent la pénétration dans cette industrie. L'entrée d'entreprises dans les secteurs commerciaux semble être plus encourageante dans les grandes villes et dans les zones à grand progrès économique. En ce qui concerne les hôtels et les restaurants, nous avons remarqué que le tourisme influence favorablement la création de nouvelles entreprises. Nous n'avons pas constaté que les règlementations régionales, récemment introduites, avaient un impact particulier sur la création de nouvelles entreprises en Italie.

Mots clés: Provinces italiennes - Initiatives stratégiques - Création d'entreprises 
International Small Business Journal 27(5)

\section{Oportunidades regionales e iniciativas de política para la creación de empresas}

Ingrid Verheul

Universidad Erasmus de Rotterdam, Países Bajos

Martin Carree

Universidad de Maastricht, Países Bajos

Enrico Santarelli

Universidad de Bolonia, Italia

Este artículo investiga los factores determinantes de la creación de empresas en los sectores y localizaciones industriales de 103 provincias italianas entre 1997 y 2003. Teniendo en cuenta las diferencias de las oportunidades regionales en todas las industrias, investigamos el impacto de una serie de factores entre los que se incluyen las iniciativas de política, sobre la creación de nuevas empresas en la fabricación, el comercio mayorista y minorista, los hoteles y restaurantes. Nuestros resultados indican que las regiones con distritos industriales se caracterizan por un índice más alto de puesta en marcha de empresas fabriles y que los costes salariales impiden la entrada en esta industria. La entrada de empresas en los sectores comerciales parece más alta en las ciudades grandes y en las zonas de gran progreso económico. En cuanto a los hoteles y restaurantes encontramos que el turismo tiene una influencia positiva sobre la creación de nuevas empresas. No encontramos ningún efecto significativo de las leyes regionales recién introducidas para fomentar la creación de nuevas empresas en Italia.

Palabras clave: Provincias italianas; iniciativas de política; creación de empresas.

\section{Regionale Chancen und Projektinitiativen für Unternehmensneugründu ngen}

Ingrid Verheul

Erasmus Universität Rotterdam, Niederlande

Martin Carree

Maastricht Universität, Niederlande

Enrico Santarelli

Universität Bologna, Italien

Dieser Artikel untersucht die ausschlaggebenden Faktoren für Unternehmensneugründungen in verschiedenen Industriezweigen und Standorten in 103 italienischen Provinzen zwischen 1997 und 2003. Unter Berücksichtigung der Unterschiede regionaler Möglichkeiten in den verschiedenen Industriezweigen untersuchen wir die Auswirkungen einer Reihe von Faktoren, einschließlich Projektinitiativen zu neuen Firmengründungen in Produktion, Einzelhandel, Großhandel, Hotel- und Gastronomiegewerbe. Unsere Ergebnisse zeigen, dass Regionen mit Industrievierteln durch höhere Neugründungszahlen in der Produktion charakterisiert werden, und dass Lohnkosten vom Eintritt in diesen Industriezweig abschrecken. Unternehmensgründungen im Handel scheinen in größeren Städten und in Gegenden mit starkem wirtschaftlichen Fortschritt zahlreicher zu sein. Im Bereich des Hotel- und Gastronomiegewerbes stellen wir fest, dass Tourismus die Neugründung von Unternehmen positiv beeinflusst. Wir konnten keine erheblichen Auswirkungen der erst kürzlich eingeführten regionalen Gesetze zur Förderung von Unternehmensneugründungen in Italien feststellen.

Schlüsselwörter: Italienische Provinzen; Projektinitiativen; Unternehmensgründung 
Verheul et al.: Regional Opportunities and Policy Initiatives for New Venture Creation 新创办企业的地区性机遇和政策举措

荷兰鹿特丹伊拉斯姆斯大学：Ingrid Verheul

荷兰萨克逊应用科技大学：Martin Carree

意大利博洛尼亚大学 : Enrico Santarelli

本文对影响意大利103个省份各个行业和地区1997年至2003年新创办企业的决定性因素做 了调查。考虑到行业由于地域的差异而机遇存在不同, 我们调查了包括政策举措在内的各 种因素对制造业、零售批发业、饭店餐馆等行业所造成的影响, 调查结果显示, 设有工业 区地区的特点是制造业企业比率较高, 此外工资成本提高了进入这个行业的门槛。进入商 业行业的公司似乎更多地集中在大城市和经济较发达地区, 而旅游对从事饭店餐馆的新创 业企业有积极的影响。我们没有发现最近推出的促进意大利新创办企业的地区法律具有重 大影响作用。

关键词：Italian provinces; policy initiatives; venture creation 